\title{
THE CONSUMER'S ATTITUDES TOWARDS WEB ADVERTISING ON TOURISM MALAYSIA WEB ADVERTISEMENT: LITERATURE REVIEW AND RESEARCH PROPOSITIONS
}

\author{
BahtiarMohamad \\ School of Multimedia Technology and Communication, Universiti Utara Malaysia \\ mbahtiar@uum.edu.my \\ NurSyuhadaRahimi \\ School of Multimedia Technology and Communication, Universiti Utara Malaysia \\ syuhada.rahimi02@gmail.com \\ ShamsuDauda Abdu \\ The Federal Polytechnic, Bauchi, Nigeria \\ shamsud.abdul@gmail.com
}

\begin{abstract}
Advertising has grown exponentially over the last 10 years. In general, advertising can be defined as the activity of a profession of producing information for promoting the sale of commercial products or services in so many ways, including the World Wide Web. For instance, advertising via the web has received much attention from people all over the world. Web advertising, in particular, has big implications to the global businesses because of wide accessibility strategies throughtout the world. Therefore, this study is carried out to identify the antecedents that influenced consumer's attitudes towards Tourism in Malaysia web advertising that is widely available. Based on a review of the existing literature in a range of fields, this study proposes a conceptual model of the positive relationships between customer's atitudewith informativeness, entertainment, credibility, economic value, interactivity and materialism.The proposed conceptual model is developed based on the Elaboration Likehood (ELM). Tourism Malaysia strongly rides on its slogan "Malaysia Truly Asia" that signifies the ever-changing and growing needs for the future. Furthermore, Tourism Malaysia web advertising also can affect the consumer's decision-making process and behavior. The researcher expects this research to make several theoretical, managerial and policy contributions. For instance, the tourism promotional board which wants to change the customer's attitude needs totake into consideration the influence factors such as informativeness, entertainment, credibility, economic value, interactivity and materialismfor the web adverstisement.
\end{abstract}

Keywords: internet, web advertising, the Elaboration Likehood Model (ELM)

\begin{abstract}
Abstak
Iklan telah tumbuh secara eksponensial selama 10 tahun terakhir. Secara umum, iklan dapat didefinisikan sebagai aktivitas profesi menghasilkan informasi untuk mempromosikan penjualan produk atau jasa komersial dalam berbagai cara, termasuk World Wide Web. Misalnya, iklan melalui web telah menerima banyak perhatian dari orang-orang di seluruh dunia. Periklanan web, khususnya, memiliki implikasi besar terhadap bisnis global karena strategi aksesibilitas yang luas keseluruh dunia. Oleh karena itu, penelitian ini dilakukan untuk mengidentifikasi anteseden yang memengaruhi sikap konsumen terhadap Pariwisata di periklanan web Malaysia yang tersedia secara luas. Berdasarkan tinjauan literatur yang ada
\end{abstract}


dalam berbagai bidang, penelitian ini mengusulkan model konseptual dari hubungan positif antara pelanggan dengan informasi, hiburan, kredibilitas, nilai ekonomi, interaktivitas dan materialisme. Model konseptual yang diusulkan dikembangkan berdasarkan Elaboration Likehood (ELM). Tourism Malaysia sangat mengandalkan slogan "Malaysia Truly Asia" yang menandakan kebutuhan yang terus berubah dan berkembang untuk masa depan. Selain itu, iklan web Tourism Malaysia juga dapat memengaruhi proses dan perilaku pengambilan keputusan konsumen. Peneliti mengharapkan penelitian ini untuk membuat beberapa kontribusi teoritis, manajerial dan kebijakan. Misalnya, dewan promosi pariwisata yang ingin mengubah sikap pelanggan perlu mempertimbangkan faktor-faktor pengaruh seperti keinformatifan, hiburan, kredibilitas, nilai ekonomi, in teraktivitas dan materialism untuk periklanan web.

Kata kunci: internet, iklan web, the Elaboration Likehood Model (ELM)

JEL: M37

\section{Research Background}

Advertising has existed for a long time and has changed over time. Advertising can be defined as a technique and practices used by company to bring products and services and persuading the public to respond in certain ways (Goldsmith \& Lafferty, 2002). Advertising isalso one of the most important sources of income for the media agencies that serve the media such as newspapers, magazines, or television stations through which it is conducted (BezjianAvery, Calder \&Iacobucci, 1998). In line with the media technology growth, there are so many changes in the use of the Internet which helps many advertising industry to adopte modern and interactive tools (Richards \& Curran, 2002).

Web advertising or web advertisement consists of transmission of impersonal commercial content paid by sponsors, designed for audiences, delivered by video, print and audio and make it more interactive and user friendly (Norzalita\& Ahmad Azmi, 2010). The advertisements which first appeared on the Web, was banner ads that ran across the top or bottom of a Web page. Basically, through the Web advertising, consumers can gather pricing information, participate in product design, explore promotions, consummate sales, arrange delivery and receive post-purchase support (Korgaonkar\&Wolin, 2002).

The emergence of the Internet Advertising has greatly benefited the consumer and advertiser. For instance, the Internet has had a profound impact on strategic thinking because of its ability to change organizational structures, cost patterns and alter communication with customers(Boudreau \& Watson, 2006). Apart from these, other potential advantages of Internet advertising includes the ability to get more information via easy click-through, the availability of more information in general, the ability to act on what interests the consumers immediately, viewer privacy, and more interesting ads (Goldsmith \& Lafferty, 2002). All these advantages became available only with the advent of Web advertising.

Therefore, this paper focuses on the influence factors of consumer's attitudes towards Tourism Web advertising. In this context, attitude can be defined as predispositions to respond in a particular way towards a specified class of objects (Rosenberg, 1960). Further, elaborates that attitude as an individual personal evaluation, emotional feeling attached and action tendency toward some objects or ideas. For example, the attitude towards the myriad of Web advertising favorable or unfavorable manner to a particular advertising stimulus during a particular exposure occasion (Lutz, 1985) on the cognitive, affective and behavioral(Saeed et al., 2013). However, some researchers have divided attitude to six categories such as informativeness, entertainment value, materialism and economic value (Norzalita\& Ahmad Azmi, 2010).

Tourism Malaysia website has been chosen as a context of study, strongly rides on its 
slogan "Malaysia Truly Asia", it signifies the ever-changing and growing needs of the future. TourismMalaysia is the global agency that promotes a variety of destinations in Malaysia.TourismMalaysia allocated RM454 million (USD103 million) for operation and promotion in 2015; a significant portion of this budget is for international advertising and promotion programmes(Tourism Malaysia, 2014).

Tourism Malaysia is repositioning its tourism campaign by focusing on Malaysia's position as a cultural melting pot: the amalgamation of the three most important civilizations in Asia - the Malays, Chinese and Indians. Formulated in 1999, launched in 2000, 'Malaysia Truly Asia' constitutes a platform for Tourism Malaysia to promote Malaysia as a brand image, rather than purely a tourist destination. The main focus of this brand image is none other than Malaysia's population multiethnicity. Through this campaign, tourists are encouraged to stay longer and enjoy Asia's multi-faceted experience in one destination - Malaysia, diversified in its cultural heritage and colourful in its customs and traditions.

Tourism Malaysia campaign is extremely professional and has proven to be very effective. Tourism Malaysiahas been promoting Malaysia as the premier holiday destination in the region. The combination of Malaysia's natural charms, rich cultural heritage, history and traditions of the various ethnic groups, forms the basis of this theme. It aims to create an easily identifiable image of Malaysia that is both attractive and easily recalled in the decision-making process of destination selection. The theme was implemented in all thematic and tactical advertising campaigns undertaken by Tourism Malaysia at the international level through web advertisement. From that, many factors influence customer's attitudes towards advertising that are likely to be seen in those who never visit the Tourism Malaysia website.

Therefore, the main objectives of this paperare to investigate the influence factors of attitudes towards Web advertising via TourismMalaysia website. The study reviews the related literature on Web advertisement that stimulates the mind and generates action in line with customer thinking. The website itself should thereforebe good at promoting interactivity,userfriendliness and ability to change one's mind as a product or brand. The method also shows that persuasion is needed in the context of this study which can be understood as the act of convincing others to think, feel or do what we want (Perloff, 1993).

Web advertisement can be defined as a way of advertising that usesthe Internet and providesinformation about the products or services with an interactive interface that gives marketers the opportunity to tocustomize their customer by creating brand awareness and brand loyalty among consumers (Saeed et al.,2013).

Many companies are turning to the Web to advertise their products or services. Consumers have more control over the web with targeted advertising exposure or in other words, the freedom to select how much commercial content they wish to view, when they want to view it, and if they want to view it at all. Throughout the site, consumers can gather pricing information, participate in product design, explore promotions, consummate sales, arrange delivery, and receive post-purchase support (Korgaonkar\&Wolin, 2002).In other words, web advertising can give great impact to their viewer.

In terms of operational influence factors of attitude towards Tourism Malaysia web advertising via a website, some researchers noted that the influence of factors of attitude usually depends on six main factors, including informativeness, entertainment value, credibility, interactivity, economy value and materialism. Here, we can see that all these independent variables have high potentials in the context influence factors of consumer's attitude towards TourismMalaysia web advertising (Choon Ling, Hoi Piew\&Teck Chai, 2010).

This study applies the Elaboration Likelihood Model (ELM) in order to identify the influence factors of consumer's attitude towards advertising via Tourism Malaysia's website. The ELM also discusses about attitudes are formed or changed (Petty \&Cacioppo, 1986). A final way in which variables can affect attitudes is by influencing the confidence people have in their thoughts. Thought confidence is important because it determines whether people will rely 
on the thoughts they have generated to form attitudes (Petty, Brinol, and Tormala, 2002).

\subsection{The Factors of Customer's Attitudes towards Web Advertisement}

The literature has indicates six important factors that influenced customer's attitude towards web advertisement. It includes (1) Informativeness, (2) Entertainment value, (3) Credibility, (4) Economic value, (5) Interactivity and (6) Materialism

Firstly, the informativesness of product and services usually includes the amount, accuracy and form of information thatis offered on a website (Elliott \& Speck, 2005). All these information is important in aiding identification, comparison and selection of products desire. Online information includes text, tables, graphs, photos, audio and video, which gives detailed explanation about the product, executes a series of prices, specification, color and variety of models. It helps online shoppers to make a decision, feel more confident about their decisions, increase satisfaction with the shopping experience and improve attitude towards a website.

Secondly, the entertainment value such as enjoyment while using a website that includes sensory and hedonic stimuli, color, music, action and interactivity which attracts a viewer to continue browsing through also leads to purchase intention. Furthermore, the website that provides entertainment such as games, contests, puzzles, streaming video and virtual tours may be able to make the website more attractive and lovable. Like conventional shoppers, eshoppers prefer experiences that create positive feelings. Past research suggested that factorsrelated entertainment included vividness, aesthetically pleasing design elements, and engaging material are positively related to attitude to a website (Chen and Wells, 1999; Coyle and Thorson 2001; Kwon, Kim, \& Lee, 2002; McMillan, Hwang \& Lee, 2003).

Third, credibility is another important factor to influende the customer's attitude. For instance, the consumer distrust of and cynicism towards advertisements impede the credibility of advertising. The credibility is a salient antecedent of attitude towards Web adverting value (Brackett \& Carr, 2001; Pllay\& Mittal, 1993). The medium of advertising messages has influenced consumer's attitudes towards the advertisement content. Therefore, a medium's reputation can either enhance or distract them from the perceived trustworthiness and believability of advertising messages placed in that media (Schiffman et al., 2010).

Fourth, economic value or condition also reflects the viewpoints of advertising that accelerates the acceptance of new products, fosters full employment, lowers the average cost of production, promotes a healthy competition between all producers to consumers' benefit, and raises the average standard of living (Belch \& Belch, 2007). Generally, a practical use of national resources increases the average standard of living, as Munusamy and Wong (2007) demonstrated. This clearly shows that economic value can portray positive attitudes towards web advertising.

Fifth, the interactive capabilitiesor multimedia element of web advertising serves to increase the potential enjoyment experienced, which in turn, contributes to the formulation of a positive attitude towards the website (Korgaonkar et al., 2001; Carlson \&O'Cass, 2011). Interactivity can be defined as an ease of use of the interface of the website such as screens uncluttered, clear organization, logical flow and ease of navigation, in short, a web design that facilitates one's efficient and effective use of the site. Ease of use should enhance the ability to process product and purchase information, reduce a cost of search and increase attitude toward the site (Chen and Wells, 1999; Kwon, Kim \& Lee, 2002; Bellman \&Rossiter 2004). It can lead to attitude to online shopping (Jarvenpaa\& Todd, 1997; Vijayasarathy\& Jones 2000). It also increases satisfaction with online shopping (Syzmanski and Hise, 2000; Yang, Peterson \& Huang, 2001).

Finally, the general meaning of materialism which can be included in the context of web advertising which is to influence buyers' unaffordability of spending, and in improving product better than web ad, dissatisfaction increases for those who cannot afford and create a materialistic society (Norzalita\& Ahmad Azmi, 2010). Materialism is also seen as one of the 
negative attitudes because the level of desire to have something that people cannot afford to buy, which may lead to financial problems. Materialism is a set of belief structures that sees consumption as the route to most, if not all, satisfactions (Munusamy\& Wong, 2007).

\subsection{Effects of Web Advertising: A Communication Perspective}

This clearly proves the aspect of advertising as one of the contributors in the communication perspective. According to Hofstede (2001), communication is not only about dissemination of information, but it also reinforces the collective of culture all over the country. In line with this, Biswas et al., (1992) and Raza, Bakar\&Mohamad, (2018a)also agree that advertising aspect strengthens not only capable, but can even establish and embodies the country's collective convictions. Other than hand, O'Cas (2005) noed that controlled brand communications, such as advertising and promotions from the service providers, have a significant positive influence on the formation of positive brand attitudes. In addition, it can be argued that controlled communication provided by an organization's website presents the consumer with an opportunity to "experience the brand" via a quality user experience (i.e. easyto-use, delivers value, is interactive, personalized and timely), which can positively influence theattitudes of consumers (Busen, Mustaffa\&Mohamad, 2016; Dayal et al., 2000). In brief, this work which stutiesthe influence factors of consumer attitudes towards advertising web (ATWA) on Tourism Malaysia's Web Advertisement is able to contribute to the development of communication perspective regardless of frontiers.

\subsection{Theoretical Underpinning}

Based on the model, Elaboration Likehood Model (ELM), which was introduced by Petty and Cacioppo (1979) it is indirectly relevant to this study. Generally, ELM has 2 routes for persuasion, involving central and peripheral routes. It involves attitudes and motivates them towards a stimulus. For example, these two routes have been applied by the viewer of Tourism's web advertisement according to the needs of each viewer. Basically, central route is most appropriately used when the receiver is motivated to think about the message and has the ability to think about the message or certain information. Lasting persuasion is likely if the receiver thinks, or rehearses favorable thoughts about the message cement that involves cognitive and for long-term changes in attitude and also involved the decision-making process.

Contrary to peripheral route, central route involves communication strategies advocated by trying to associate the position with what the receiver already thinks things positively about, for example, towards food or money using an expert appeal and so on. Here, when they are feeling good, they will want to sustain viewing Malaysia Tourism's website and will avoid focusing on things that might bring them down again, so they take a more cursory look, and that's what it called peripheral route. In this study, the attitudes are more inclined towards the central routes is informativeness, credibility and economic value. Through information or message that has been provided through Malaysia Tourism's website, it's clearly shown that viewer has the ability to engage in issue-relevant thinking. Besides that, because of their trustworthiness and belief towards all the content of the information in Malaysia Tourism's website, they are able to elaborate the information. In line with that, they are able to engage with the economic value where some of them believe that people wear branded clothes because of the Malaysia Tourism's web advertisement.

Peripheral routes that involved in this study comprise three main aspects, which are entertainment, interactivity and materialism. This can be seen through the website of Malaysia Tourism that has innovative features, creativity and good looks. It is some kind of ways to attract or to persuade viewers to maintain Malaysia Tourism's website viewing. In addition, through interactivity aspect, visuals of Malaysia Tourism products sound, feel, look real and keep viewers' attention. Lastly, materialism aspect makes viewers have interest in any product 
of Malaysia Tourism and materialistic society sometime makes some other people just to show off by viewing or having any product of Tourism. All of this usually "automatic, shallow, heuristic, and mindless' and based on affective associations or simple inferences tied to peripheral cues" (Petty \&Cacioppo, 1986). Thus, this study clearly shows that ElobarationLikehood Model (ELM) interrelated with the influence factors of consumer's attitudes towards advertising web (ATWA) on Malaysia Tourism web advertisement.

\section{Research Framework and Propositions Development}

Figure 1 shows the conceptual framework between the independent variables and the dependent variable.

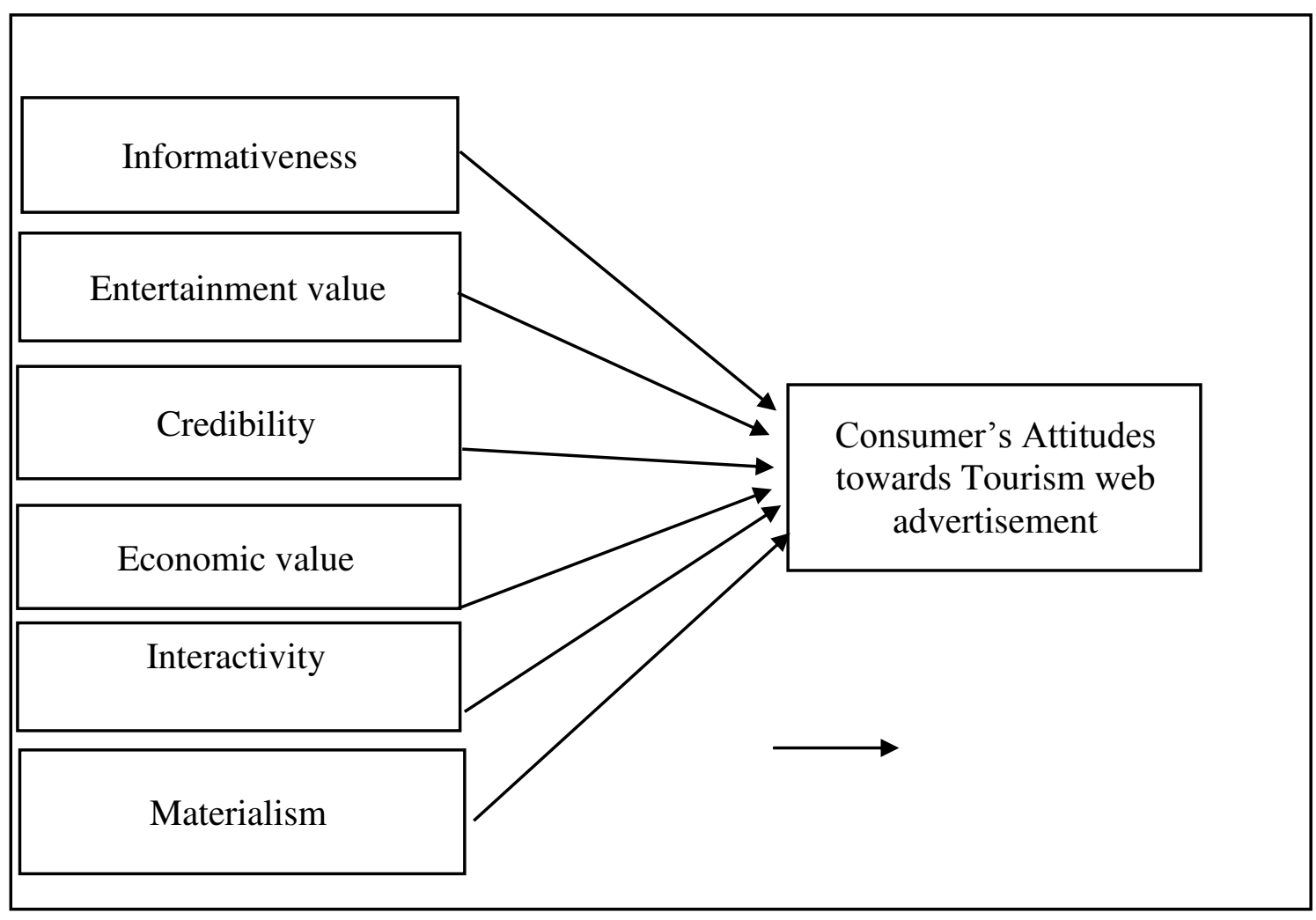

Figure 1.

Conceptual Framework

Providing information on products or services is one of the main reasons web advertisement exist. Informativeness includes brand in terms of features, convenience source, keep up to date, valuable source, and pleasure in thinking and assists consumers to decide (Norzalita\& Ahmad Azmi, 2010). It's particularly important for consumers to view their attitude towards certain websites and see the extent to which advertising gives effect to them. In addition, Schlosser, Shavitt\&Kanfer, (1999) found that a majority of respondents generally liked their advertising and that most of those respondents liked it because they felt it was informative.Usually, the quality of that information or message placed on a company's website shows a direct influence on the customers' perceptions of the company and the company's products. At the same time, information delivered to them via online media also needs to show qualitative features, such as accuracy, timeliness and usefulness for the consumer (Siau\&Shen, 2003).

We can thus conclude that the use of web advertising is able to give a more detailed info about a product or service. Calfee and Ringold (1994) reported that any advertisement that 
provides product information, leading to consumer education. They are able to explain to the target audience of the goals, expectation and values regarding the organization as well let them know what offers organizations, and consumers need. From that, maybe some improvement can be done to fullfill all the satisfaction for both. Hence, it can be expected that there is a strong relationship between informativeness with the influence factors of consumer's attitudes towards Tourism Malaysia web advertising. Therefore:

P1: There is a relationship between informativeness and the influence factors of consumer's attitudes towards Tourism Malaysia web advertising.

In this study, entertainment value is related to Hedonic / pleasure that indicates that ads can be entertaining, sentimental, expressive, and exciting (Pollay\& Mittal, 1993). In addition, feelings of people about enjoyment of ads play significant and important roles in forming their general attitudes toward ads (Raza, Bakar\&Mohamad, 2018b; Saadeghvaziri\&Seyedjavadain, 2011), which includes feeling good, enjoyable and social image (Norzalita\& Ahmad Azmi, 2010), using well-known people such as an artist who is indirectly able to bring products or services to a consumer. It is also able to attract a consumer to know about the products or services with more details and make it become more interesting while browsing through the website. When we surf the Internet, it also gives a sense of satisfaction and enjoyable, especially when the advertiser using our very own favorite artists as a social image in the website. In fact, entertainment denotes its full ability to fulfill consumers' needs for 'escapism, diversion, aesthetic enjoyment or emotional release (McQuail, 1983).

Entertainment is required in everyone who allows people to forget about the real problems of life for a while by looking for something that can ease their tension or stress. At the same time, entertainment can increase customer loyalty and add value for the product and organization. In this case, as most of the people have a natural playfulness, providing games and prizes via the Internet involved high participation. By delivering games and prizes to the customers through Internet ads is a successful way to attract and keep customers. For example, the latest program conducted by Tourism Malaysia by viewing the Tourism website, you're invited to join Malaysia Year-End Sale 2016 and served with a contests, promotions, cultural performance, and authentic gastronomic adventures.and many more. Tourism Malaysia is always trying to attract the attention of the tourist by providing something fun and interesting. Therefore, it can be proposed:

P2: There is a relationship between the entertainment values to the influence factors of consumer's attitudes towards Tourism Malaysia web advertisement.

Meanwhile, credibility can be defined as a believability of the addressor and its perception in the listener's mind (Zha\& Yan, 2015; Adler \& Rodman, 2000). MacKenzie and Lutz (1989) also identify advertising credibility as consumers' general perception towards the truthfulness, reliability, trustworthiness and believability of an advertisement, whether product or services. The credibility of advertising is not limited to traditional advertising, even with the advent of more advanced technology, it is necessary to focus mainly on advertising via the web site or new media. In brief, credibility is about the quality of being believed or accepted as true, real, or honest. In line with the believability, trustworthy is also an important aspect in one's attitude toward web advertising. According to $\mathrm{Li}$ and Zhang (202), the level of trust, interpersonal as well as institutional, is obviously related to consumers' attitude and their intention to shop on the Internet.

Nowadays, violation of consumers trusts in on-line shopping, in terms of privacy invasion or misuse of personal information, negatively influences an attitude toward online 
shopping and leads to reluctant behavior among consumers to shop on the Internet whether via website or new media in future occasions. If there is no believe on the information given by the advertisement, then there will be no trust by a person on the advertisement (Saeed et al., 2013). Therefore, brand awareness is very important in ensuring trust in any products or services towards consumers. Thus, honesty is the best policy. Be authentic and genuine in business or dealing with consumers because it is what all of us are looking for. In this context, we can see that there is a connection between the credibility of the Tourism Malaysia and destination product. Therefore, the next proposition could be:

P3: There is a relationship between the credibility and the influence factors of consumer's attitudes towards Tourism Malaysia web advertising.

Apart of this, good for the economy is also one of the influence factors of attitude towards web advertising (Pollay\& Mittal, 1993) It indicates that our ads should increase life standards, resulting in full employment, intense competition among companies and declining average product cost. This clearly shows that the economic value is more to win-win situation between the advertiser and consumer. Besides that, it is good for the economy to associate with necessary to support web, other users (buying and selling), improves the standard of living and reassures using a right product (Norzalita\& Ahmad Azmi, 2010). Web advertising enables consumers to save their time, purchase without a hassle, have many choices, and increase the acceptance of new services and products (Pollay\& Mittal, 1993; Wolin et al., 2002).

Tourism Malaysia has portrayed Malaysia as an affordable destination with quality life and advanced transportation system to assure comfortability to tourist. However, not everyone can afford to have it. Thus, the concept of good for economy or economic value reflects the points of view that advertising speeds up the adoption of new goods and technologies by consumers, fosters full employment, reduces the average costs of production, elevates producers about healthy competition, and increases the standard of living on average (Belch and Belch, 2008). Therefore:

P4: There is a relationship between economic values with the influence factors of consumer's attitudes towards Tourism Malaysia web advertising.

Interactivity is measured by two-way communication (or vividness), control, frequency of exchange, and customization (Zhang \& Wang, 2005). It clearly related to virtual interactivity of interpersonal communication where people can interact with each other, especially through social dialogue box or any social media that linked to the website to get to know about the product. Through interactivity, it indirectly facilitates the consumer to make a choice without the need to go to the company to make a choice.

At the same time,Cho and Leckenby (1999) found that the user's intentions to interact with a site and the actual number of interactive features at a site were both positively related to attitude towards the site. For example, through the website of Tourism Malaysia, was declared the details destination and new update (Tourism Malaysia, 2014). This can be seen through the Tourism websites where the use of an appropriate layout, videos and websites that are linked to social media such as Facebook. Therefore, it can be proposed.

P5: There is a relationship between the interactivity and the influence factors of consumer's attitudes towards Tourism Malaysia web advertising.

General meaning of materialism which can be included in the context of web 
advertising is to influence buys unaffordable, spending in product improvement better than web advertisement, dissatisfaction increases for those who cannot afford and create a materialistic society (Norzalita\& Ahmad Azmi, 2010). Materialism is also seen as one of the negative attitudes because the level of desire to have something that cannot afford to buy, which may lead to financial problems.Materialism is a set of belief structures that sees consumption as the route to most, if not all, satisfactions (Ting \& Run, 2015; Munusamy\& Wong, 2007).

The situation will get worse if left unchecked and eventually become a part of a materialistic society in buying and owning things. In fact, Korgaonkar, Silverblatt\& O'Leary (2001) also considered that web advertising makes people buy unaffordable products just to show off. For example, a person that has a desire to travel will be influenced by Tourism Malaysia web advertisement because it is an established tourism board and looks exclusive. Therefore, it can be proposed:

P6: There is a relationship between materialism and the influence factors of consumer's attitudes towards Tourism Malaysia web advertising.

\section{Conclusion}

In summary, the conceptual model as depicted by Figure 1 is based on a review of existing research in the fields of advertising, marketing and management communication corporate leadership as well as tourism. It was conducted to determine the influence factors of attitudes towards Tourism Malaysia web advertisement. Overall, the literatures are relatively promising and emphasize the influence factors of consumer's attitudes towards advertising web (ATWA) on Malaysia Tourism web advertisement. This study established that all the independent variables, which involved informativeness, entertainment, credibility, economic value, interactivity and materialism, are among the influence factors of consumer's attitudes towards Malaysia Tourism's web advertisement. At the same time, this proves informativeness factors play an important role in attracting viewers to browse through Malaysia Tourism website. It also shows that Malaysia Tourism's web advertisement assists the viewer in finding adequate information regarding the product that they want. This includes terms of price, specification, design and so on.

In addition, the entertainment aspect of Tourism Malaysia website includes website visualization, creativity and innovative concept that are applied in Tourism Malaysia's website. This adds excitement to continue towards consumer's to view Tourism Malaysia's website and stimulate them towards intention to visit destination. Moreover, Tourism Malaysia destination product brand that can be trusted and that which aired on Tourism Malaysia's website is the same as in reality. It directly can create brand loyalty among tourists. In terms of economic value, viewing any product of Tourism Malaysia's website can improve their lives.

Other than that, in accordance with the passage of time, advertising on the website has also changed. The changes also apply to Tourism Malaysia's web advertisement. With an attractive interface and sounds and looks like a real model or 3D can stimulate their interest to keep viewing the Tourism Malaysia website. In addition, Tourism Malaysia's web advertisement load fast and make people less annoyed. In brief, there are many factors that can influence the consumer's attitudes towards advertising web (ATWA) on Tourism Malaysia web advertisement. However, it depends on everyone and what are the reasons that stimulate them to view the ads or what excites them. Therefore, this paper was providing a new pathway in ATWA especially towards Tourism's web advertisement.

\section{References}


Adler, R. B., \& Rodman, G. (2000) Understanding human communication, (7th edn). Ft Worth, TX:Harcourt College Publishers.

Andersen, S.O. \&Zaelke, D. (2003), Industry Genius: Inventions and People Protecting the Climate and Fragile Ozone Layer, Greenleaf Publishing, Sheffield.

Azeem, A., \&Haq, Z. (2012). Perception towards Internet Advertising : A study with Reference to Three Different Demographic Groups. Journal Business and Management Research: An International Journal, 4(1), 28-45.

Bassam Mahmoud, A. (2014). Linking information motivation to attitudes towards Web advertising. Journal of Islamic Marketing, 5(3), 396-413.

Belch, G. \& Belch, M. (2007) Advertising and promotion: An integrated marketing communication perspective. CA:McGraw-Hill.

Bezjian-Avery, A., Calder, B., \&Iacobucci, D. (1998). New Media Interactive Advertising vs. Traditional Advertising. Journal of Advertising Research, 1-10.

Bellman, S., \&Rossiter, J. (2004). The Website Schema. Journal of Interactive Advertising, 4(2), 38-48.

Biswas, A., Olsen, J. and Carlet, V. (1992), "A comparison of print advertisements from theUnited States and France”, Journal of Advertising, 21(4), 73-81.

Boudreau, M., \& Watson, R. (2006). Internet Advertising Strategy Alignment. Internet Research, 16(1), 23-37.

Busen, S. M. S., Mustaffa, C. S., \&Bahtiar, M. (2016). Impacts of attitude towards online banner advertisement on brand awareness: Insight from persuasive hierarchy model. Mediterranean Journal of Social Sciences, 7(3 S1), 81.

Bracket, L.D. \& Carr, B.N. (2001). Cyberspace advertising vs other media: Mature student attitudes. Journal of Advertising Research, 41(5), 23-32.

Bryman, A. (2006). Integrating Quantitative and Qualitative Research: How is it done? Qualitative Research, 6(1), 97-113.

Calfee, J., \&Ringold, D. (1994). The 70\% majority: enduring consumer beliefs about advertising. Journal of Public Policy \& Marketing, 13, 228-238.

Choon Ling, K., Hoi Piew, T., \&Teck Chai, L. (2010). The Determinants of Consumers' Attitude towards Advertising. Canadian Social Science, 6(4), 114-126.

Chen, Q., Clifford, S., \& Wells, W. (2002). Attitude Toward The Site II: New Information. Journal Of Advertising Research, 42(2), 33-45.

Chen, Q., \& Wells, W.D. (1999). Attitude toward the site. Journal of Advertising Research, 40(5), 27-37.

Coyle, J.R., \& Thorson, E. (2001). The effects of progressive levels of interactivity and vividness in web marketing sites. Journal of Advertising, 41(3), 65-77

Dayal, S., Landesberg, H. and Zeisser, M. (2000), "Building digital brands", The McKinsey Quarterly, 2, 42-51.

Donsbach, W. (2008). The International Encyclopedia of Communication. Malden, MA: Blackwell Pub.

Donthu, N. (2001). Does Your Web Site Measure Up? Marketing Management, 10(4), 39-32.

Ducoffe, R.H. (1996). Advertising value and advertising on the Web. Journal of Advertising Research, 36(5), 21-35.

Elliott, M., \& Speck, P. (2005). Factors that Affect Attitude toward a Retail Web Site. Journal of Marketing Theory And Practice, 13(1), 40-51.

Eze, U., \& Lee, C. (2012). Consumers' Attitude towards Advertising. International Journal of Business and Management, 7(13).

Goldsmith, R., \& Lafferty, B. (2002). Consumer response to Web sites and their influence on advertising effectiveness. Internet Research, 12(4), 318-328.

Goodwin, L. D., \& Leech, N. L.(2006). Understanding correlation: Factors that affect the size of r. The Journal of Experimental Education, 74(3), 249-266. 
Hofacker, C., \& Murphy, J. (1998). World Wide Web banner advertisement copy testing. European Journal of Marketing, 32(7/8), 703-712.

Hootman, R. (1992). Manual on descriptive analysis testing for sensory evaluation. Philadelphia, PA: ASTM.

Hofstede, G. (2001), Culture's Consequences: Comparing Values, Behaviors, Institutions, and Organizations Across Nations, 2nd ed., Sage, Thousand Oaks, CA.

Ida E. Berger, Peggy H. Cunningham, and Robert V. Kozinets (1999), ,Consumer Persuasion Through Cause-Related Advertising", in NA - Advances in Consumer Research Volume 26, eds. Eric J. Arnould and Linda M. Scott, Provo, UT : Association for Consumer Research, Pages: 491-497.

Jackson, S.L. (2009). Research Methods and Statistics: A Critical Thinking Approach 3rd edition. Belmont, CA: Wadsworth.

Kolter, P. (2000). Marketing management. Englewood Cliffs, NJ: Prentice Hall.

Korgaonkar, P., \&Wolin, L. (2002). Web usage, advertising, and shopping: relationship patterns. Internet Research, 12(2), 191-204.

Korgaonkar, P., Silverblatt, R., \& O’Leary, B. (2001). Web advertising and Hispanics. Journal of Consumer Marketing, 18(2), 134-152.

Krejcie, R.V., \& Morgan, D.W., (1970). Determining Sample Size for Research Activities. Educational and Psychological Measurement.

Kwon, O., Kim, C., \& Lee, E. (2002). Impact of website information design factors on consumer ratings of web-based auction sites. Behaviour\& Information Technology, 21(6), 387-402.

Li, N., \& Zhang, P. (2002). Consumer Online Shopping Attitudes and Behavior :An Assessment of Research. Eighth Americas Conference on Information Systems, 508514.

Lutz, RJ. 1985. Affective and Cognitive Antecedents of Attitude toward the Ad : A conceptual framework, In Psychological Processes and Advertising Effects :Theory, Research and Application, eds. L.F. Alwitt and A.A. Mitchell 45-46. Hillsdale: Lawrence Erlbaum Associates.

Mackenzie, S.B. and Lutz, R.L. (1989) An empirical examination of the structural antecedents of attitude toward the ad in an advertising pre testing context. Journal ofMarketing 53 (April): 48-65.

Malaysia, H. (2014). The Official Home of Tourism Malaysia. Tourism.com.my. Retrieved 28 April 2015, from http://www.tourism.com.my

Malina, M., Norreklit, H., \&Selto, F. (2011). Lessons learned: advantages and disadvantages of mixed method research. Qualitative Research In Accounting \& Management, 8(1), 5971.

McQuail, D. (1983) Mass Communication Theory: An Introduction. London: Sage Publication.

McMillan, S., Hwang, J., \& Lee, G. (2003). Effects of structural and perceptual factors on attitudes toward the website. Journal of Advertiisng Research, 43(4), 400-409.

Mehta, A. (2000), "Advertising attitudes and advertising effectiveness", Journal of Advertising Research, Vol. 40 No. 3, pp. 67-72.

Metin, I., \&MetinCamgoz, S. (2011). The Advances in the History of Cognitive Dissonance Theory. International Journal of Humanities And Social Science, 1(6), 1-6.

Munusamy, J., \& Wong, C. H. (2007). Attitude towards advertising among students at private higher learning institutions in Selangor. UniTAR e-Journal 3, 31-51.

Mukaka, M.M. (2012). A Guide To Appropriate Use Of Correlation Coefficient In Medical Research. Malawi Medical Journal, 24(3), 69-71.

NorzalitaAbd. Aziz \& Ahmad Azmi M. Ariffin. (2010).Exploring Consumers Attitude towards Web Advertising and its Influence on Web Ad Usage in Malaysia. JurnalPengurusan, 31, 55-63. 
O'Cass, A. and Pecotich, A. (2005), "Exploring the dynamics of voter behavior and influence processes in electoral markets: a consumer behavior perspective", Journal of Business Research, 58(4), 406-13.

Paton, R., \&Karunaratne, N. (2009). Engagement and innovation: the Tourism case. VINE, 39(4), 280-297.

Patsioura, F., Vlachopoulou, M., \&Manthou, V. (2009). A new advertising effectiveness model for corporate advertising web sites. Benchmarking, 16(3), 372-386.

Perloff, R.M. (1993). The Dynamics of Persuasion, Lawrence Erlbaum Associates, Hillside, NJ.

Petty, R., Cacioppo, J., \& Schumann, D. (1983). Central and Peripheral Routes to Advertising Effectiveness: The Moderating Role of Involvement. Journal of Consumers, 10(2), 135.

Petty, R.E. \&Cacioppo, J.T. (1986) Communication and Persuasion: Central and Peripheral Routes to Attitude Change. New York: Springer.

Pollay, R.W. \& Mittal, B. (1993), Here's the beef: factors, determinants, and segments in consumer criticism of advertising, Journal of Marketing, 57( 3), 99-114.

Prendergast, G., Liu, P. \& Poon, D.T.Y. (2009). A Hong Kong study of advertising credibility. Journal of Consumer Marketing, 26(5), 320-329.

Raza, S. H., Bakar, H. A., \&Mohamad, B. (2018a). Advertising appeals and Malaysian culture norms. Journal of Asian Pacific Communication, 28(1), 61-82.

Raza, S. H., Bakar, H. A., \&Mohamad, B. (2018b). Relationships between the advertising appeal and behavioral intention: The mediating role of the attitude towards advertising appeal and moderating role of cultural norm. Journal of Business and Retail Management Research, 12(2).

Rosenberg, M.J., (1960). An analysis of affective-cognitive consistency. In: Hovland, C.I., Rosenberg, M.J. (Eds.), Attitude Organization and Change. Yale University Press Inc., CT, 15-64.

Richards, J. and Curran, C. (2002), Oracles on advertising: searching for a definition. Journal Advertising, 31(2), 63-77.

Rowley, J. (2014). Designing and using research questionnaires. Management Research Review, 37(3), 308-330.

Saadeghvaziri, F., Dehdashti, Z., \& Reza KheyrkhahAskarabad, M. (2013). Web advertising. Journal of Economic And Administrative Sciences, 29(2), 99-112.

Saadeghvaziri, F. \&Seyedjavadain, S. (2011), Attitude toward advertising: mobile advertising vs. advertising-in-general, European Journal of Economics, Finance and Administrative Sciences, 28(28), pp. 104-114.

Saeed, R., Lodhi, R., Naeem, A., Akbar, A., Sami, A., \&Dustgeer, F. (2013). Consumer's Attitude towards Internet Advertising in Pakistan. World Applied Sciences Journal, 25(4), 623-628.

Schlosser, A., Shavitt, S., \&Kanfer, A. (1999). Survey of Internet User's Attitude toward Internet Advertising. Journal of Interactive Advertising, 13(3), 1-21.

Schiffman, L.G., Kanuk, L.L. \&Wisenblit, J. (2010). Consumer behavior (10th ed.). New Jersey: Pearson Prentice Hall.

Stevenson, J., Bruner, G., \& Kumar, A. (2000). Webpage Background and Viewer Attitudes.Journal Of Advertising Research, 40(1-2), 29-34.

Siau, K. and Shen, Z. (2003) Building customer trusts in e-mail commerce. Communications of the ACM 46(4): 91-94.

Sun, Y., Lim, K., Jiang, C., Peng, J., \& Chen, X. (2010). Do males and females think in the same way? An empirical investigation on the gender differences in Web advertising evaluation. Computers In Human Behavior, 26(6).

Szymanski, D., \&Hise, R. (2000). E-satisfaction: An initial Examination. Journal Of 
Retailing, 76(3), 309-322.

Teo, H. H., Oh, L. B., Liu, C., \& Wei, K. K. (2003). An Empirical study of the effects of Interactivity on Web User Attitude. International Journal of Human-Computer Study, 58, 281-305.

Ting, H., \& de Run, E. C. (2015). Attitude towards advertising: a young generation cohort's perspective. Asian Journal of Business Research ISSN, 5(1), 2015.

Vijayasarathy, L., \& Jones, J. (2000). Print and Internet catalog shopping: assessing attitudes and intentions. Internet Research, 10(3), 191-202.

Wang, Y. \& Sun, S. (2010). Examining the role of beliefs and attitudes in online advertising: a comparison between the USA and Romania. International Marketing Review, 27(1), 87106.

$\mathrm{Wu}, \mathrm{G}$. (2005). The Mediating Role of Perceived Interactivity in the Effect of Actual Interactivity on Attitude toward the Website. Journal of Interactive Advertising, 5(2), 29-39.

Yang, Z., Peterson, R.T., \& Huang, L. (2001). Taking the pulse of internet pharmacies. Marketing Health Services, 21(2), 4-10.

Zha, X., Li, J., \& Yan, Y. (2015). Advertising value and credibility transfer: attitude towards web advertising and online information acquisition. Behaviour\& Information Technology, 34(5), 520-532.

Zhang, P., \& Wang, C. (2005). An Empirical Study on Consumer's Perceived Value and Attitude towards Advertising. Proceedings of the 6Th Global Information Technology And Management (GITM) World Conference.

Zheng Zhou and YeqingBao (2002),"Users Attitudes Toward Web Advertising: Effects of Internet Motivation and Internet Ability", in NA - Advances in Consumer Research Volume 29, eds. Susan M. Broniarczyk and Kent Nakamoto, Valdosta, GA : Association for Consumer Research, Pages: 71-78. 